3. Zhao L, Zhu Y, Chen Z, Xu H, Zhou J, Tang S, Xu Z, Kong F, Li X, Zhang Y, Li X, Zhang J, Jia G. Cardiopulmonary effects induced by occupational exposure to titanium dioxide nanoparticles. Nanotoxicology. 2018; 12(2):169-184

4. Bostan H.B., Rezaee R., Valokala M.G., Tsarouhas K., Golokhvast K., Tsatsakis A.M., Karimi G. Cardiotoxicity of nanoparticles. Life Sciences. 2016; 165: 91-99. DOI: 10.1016/j.lfs.2016.09.017

5. Warheit D.B. Hazard and risk assessment strategies for nanoparticle exposures: how far have we come in the past 10 years? F1000Res. 2018; 7:376. https:// doi.org/10.12688/f1000research.12691.1.

DOI https://doi.org/10.30525/978-9934-588-81-5-2.33

\title{
ОЦНКА ЗАПАЛЬНОГО ПРОЦЕСУ \\ ПРИ ЕКСПЕРИМЕНТАЛЬНОМУ ВАГІНІТІ ТА ЗА УМОВ КОРЕКЦІЇ ВАГІНАЛЬНИМИ СУППОЗИТОРІЯМИ «КЛІМЕДЕКС» ТА «МЕЛАНІЗОЛ»
}

\author{
Должикова О. В. \\ кандидат фармачевтичних наук, \\ дочент кафедри клінічної лабораторної діагностики \\ Наиіональний фармачевтичний університет \\ Срьоменко Р. Ф. \\ доктор біологічних наук, \\ професор кафедри клінічної лабораторної діагностики \\ Наиіональний фармацевтичний університет \\ Козар В. В. \\ кандидат медичних наук, \\ доцент кафедри клінічної лабораторної діагностики \\ Національний фармачевтичний університет \\ м. Харків, Україна
}

Лікування вагінітів визначається адекватною та своєчасною антимікробною терапією. Оскільки дуже часто первинний перебіг запальних захворювань геніталій має мінімальні клінічні прояви та тенденцію до хронізації процесу, стандартна антибіотикотерапія не завжди в таких випадках $є$ ефективною, що обумовлено багатьма чинниками, як то розвиток стійкості мікроорганізмів до антибіотиків, алергізація в результаті тривалого застосування антибіотиків тощо. Тому продов- 
жується пошук дієвих композицій для лікування вагінітів, зокрема, поєднання антибіотиків із природними антибактеріальними / антифунгальними сполуками [1].

Основним патофізіолочним процесом при вагінітах являється запалення, виразність якого залежить від гостроти процесу, тому для оцінки ефективності терапії є важливим визначати маркери запалення в динаміці. Одним із таких маркерів запалення $є \mathrm{C}$-реактивний білок (СРБ), що належить до сімейства пентраксинів, і який серед білків гострої фази має найбільший динамічний діапазон. Концентрація СРБ після подразника відбувається дуже швидко, через 6-8 годин може досягати в окремих випадках 1000 мг/л. Що ще важливіше, рівень СРБ також швидко знижується після того, як відбулося вирішення збудливої події. Це робить його більш корисним, ніж широко застосовуваний показник швидкості осідання еритроцитів (ШОЕ), який залишається підвищеним довгий час після розв'язання запального стану [2]. Саме тому Міжнародний Комітет по Стандартизації гематологічних досліджень рекомендує кількісне визначення СРБ як більш значимий показник запалення, ніж ШОЕ.

Мета. Визначити стан запалення за концентрацію С-реактивного білка у сироватці крові тварин із експеритентальним вагінітом та за умов застосування вагільнальних суппозиторіїв «Клімедекс» та «Меланізол».

Матеріали та методи. Дослідження проведено на нелінійних статевозрілих щурах-самках масою $190 \pm 10$ г. відповідно до правил «Свропейської конвенції захисту хребетних тварин, що використовуються в наукових цілях» (Страсбург, 1985) та принципами Національного конгресу України з біоетики (Київ, 2001). Тварин утримували на стандартному раціоні віварію

Вагініт моделювали шляхом одноразової внутрішньої аплікації іританта, в якості якого застосовували суміш скіпидару (Товариство 3 обмеженою відповідальністю «Янтар», Україна) з диметилсульфоксидом (Dimexid, «Arterium», ТОВ «Галичфарм», Україна) у співвідношенні $1: 1$ в дозі 0,5 мл/100 г маси тіла тварини. Через 24 години після введення іританта починали лікування. Досліджувані препарати вводили в піхву протягом 7 днів 1 раз на добу (гостре запалення). Субхронічне запалення моделювали тим же іритантом 1-й раз 0,5 мл / 100 г маси тіла тварини, потім через кожні 5 діб 0,25 мл / 100 г маси тіла тварини 5 разів. Лікування починали 3 першої доби розвитку патології введенням суппозторіїв протягом 7 та 29 діб.

В якості досліджуваних препаратів були взяті супозиторії, композиції яких розроблені в Національному фармацевтичному університеті 
(м. Харків, Україна): «Меланізол» (1 супозиторій містить: метронідазолу 250 мг, олії чайного дерева 100 мг суміш суппозиторної основи ПЕО-1500 і ПЕО-400 (9: 1) [3], «Клімедекс» (1 супозиторій містить: кліндаміцину фосфат 100 мг, метронідазолу 150 мг, флуконазолу 100 мг, дексаметазону 0,5 мг, олії обліпихової 200 мг, суміш ПЕО-1500 і ПЕО-400 (9: 1).

Кожна експериментальна група, складалася з 8 самок щурів. Тварини були розділені на групи в такий спосіб: 1 група - інтактні тварини (ІК); 2 група - тварини 3 вагінітом (контрольна патологія - КП); 3 група - тварини з вагінітом, які отримували плацебо - супозиторну основу в еквівалентній кількості (плацебо; негативний контроль; суміш РЕО-1500 і РEО-400 (9: 1) (КП+плацебо); 4 група - тварини із вагінітом, яких лікували вагінальними супозиторіями Меланізол (КП+ «Меанізол», 5 група - тварини із вагінітом, яких лікували вагінальними супозиторіями «Клімедекс» (КП+ «Клімедекс»). Досліджувані супозиторії вводили вагінально 1 раз на добу в дозах, розрахованих із використанням застосовуваних в експериментальної фармакології коефіцієнтом видової стійкості Риболовлєва Ю.Р. [3].

На 8 та 30 добу тварин виводили з експерименту методом шляхом декапітації під легким ефірним наркозом. Після декапітації тварин відбирали кров, яку потім використовували для отримання сироватки.

Визначення концентрації СРБ в сироватці крові проводили напівкількісним методом латексної аглютинації з чутливістю 1,0 мг/л СРБ [4].

Статистичну обробку отриманих результатів проводили за допомогою програми «Statistica 6.0» з використанням параметричних критеріїв.

Результати дослідження. В ініціюванні гострого запалення піхви встановлено значне підвищення концентрації СРБ у сироватці крові щурів групи контрольної патології у порівнянні з інтактним контролем $(20,00 \pm 2,62$ мг/л проти $1,88 \pm 0,13$ мг/л на 1 добу та $10,00 \pm 1,31$ проти $1,75 \pm 0,16$ мг/л на 8 добу, $\mathrm{p} \leq 0,05)$, тобто майже в 10 і 5 разів відповідно на 1 та 8 добу експерименту. Отримані результати вказують на наявність запалення, тобто адекватність вибору моделі вагініту.

Застосування суппозиторіїв «Меанізол» та «Клімедекс» на 1 добу практично не вплинуло на розвиток запалення і показники не відрізнялися від аналогічних контрольної патології. На 8 добу обидві композиції вірогідно знизили концентрацію СРБ в сироватці дослідних

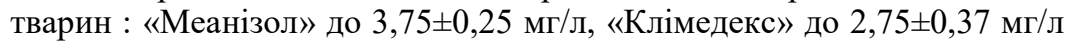
( $\mathrm{p} \leq 0,05)$, що свідчить про наявність виразних протизапальних властивостей у суппозиторіїв. Слід зауважити, що ефект «Меланізолу» поступався «Клімедексу» $(\mathrm{p} \leq 0,05)$. 
Отже, за умов гострого запалення більш дієвими виявилися суппозиторії «Клімедекс», в склад яких входить три види антимікробних препаратів та дексаметазон, який також має протизапальні властивості, обумовлені, перш за все, зменшення проникності судин, а отже i такої фази запалення, як ексудація.

За умов моделювання субхронічного запалення встановлено, що у тварин контрольної патології концентрація білка залишалася підвищеною $(9,00 \pm 1,00$ мг/л) у порівнянні $з$ інтактним контролем $(\mathrm{p} \leq 0,05)$. За даних умов більш ефективним виявилося застосування суппозиторіїв «Меланізолу»,які зменшили концентрацію СРБ до 2,13 $\pm 0,30$ мг/л і вірогідно не відрізнялися від значень інтактних тварин. У той же час, використання «Клімедексу» знизило концентрацію СРБ лише до $5,00 \pm 0,065$ мг/л, і у порівнянні з гострим процесом цей показник збільшився майже вдвічі.

Отримані результати показали, що за гострого процесу введення протягом тижня комбінації декількох видів антибіотиків та дексаметазону є дієвою стратегією. Однак, при тривалому застосуванні такі препарати можуть призвести до розвитку антибіотикорезистентності, дисбіозу, алергії, імунодепресії (наприклад, дексаметазон пригнічує активність лімфоцитів) тощо, а отже і хронізації запалення. Таке припущення підтверджується нашим експериментом, який продемонстрував через 30 днів на фоні введення «Клімедексу» не зниження, зростання концентрації СРБ.

За аналогічних умов «Меланізол», який містить один антибіотик та масло чайного дерева, відомого засобу з антисептичними, бактеріостатичними, мембранопротекторними та іншими властивостями, виявився більш дієвим саме за умов хронічного запалення. Це важливий результат, оскільки вагініти схильні до хронізації, що потребує більш тривалого застосування антибактеріальних препаратів.

Висновки. Вагінальні суппозиторії «Меланізол» і «Клімедекс» проявлять виразні протизапальні властивості. При цьому, «Клімедекс» віявився ефективнішим при короткочасному застосуванні, а «Меланізол» - при тривалому.

\section{Література:}

1. Zeyan Lin, Yanyan Lin, Zhengbing Zhang et al. Systematic analysis of bacteriostatic mechanism of flavonoids using transcriptome and its therapeutic effect on vaginitis //Aging (Albany NY). 2020. V. 12, N. 7. C. 6292-6305. 
2. Terry W. Du Clos. Pentraxins: Structure, Function, and Role in Inflammation // ISRN Inflamm. 2013; 2013: 379040. Published online 2013 Sep 14. doi: 10.1155/2013/379040/

3. Рыболовлев Ю.Р. Дозирование веществ для млекопитающих по константам биологической активности [Текст] / Ю.Р. Рыболовлев, Р.С. Рыболовлев // Доклады АН СССР, 1979. Т. 247. № 6. С. 1513-1516.

4. Пат. 38911 UA, МПК (2009) G01N33/544. Спосіб визначення концентрації С-реактивного білка експрес-методом / В. В. Козар, М. Я. Кудря (UA); заявник і патентовласник ДУ «Інститут проблем ендокринної патології ім. В. Я. Данилевського АМН України» (UA). № u200810068; заявл. 04.08. 2008; опубл.26.01.2009 Бюл. № 2 - 6 с.

DOI https://doi.org/10.30525/978-9934-588-81-5-2.34

\section{ВПЛИВ РАЦІОНУ $З$ НАДЛИШКОМ ПОЖИВНИХ РЕЧОВИН МАТЕРІВ НА СТРУКТУРНІ ЕЛЕМЕНТИ ТА ПОКАЗНИКИ ЖИРОВОГО ОБМІНУ СИРОВАТКИ КРОВІ ЇХНЬОГО ОДНОМІСЯЧНОГО ПОТОМСТВА}

Кузнецова М. О.

асистент кафедри патологічної фізіології імені Д. О. Альперна Харківський начіональний медичний університет

Ніколаєва О. В.

доктор медичних наук, завідувач кафедри патологічної фізіології імені Д. О. Альперна Харківський національний медичний університет

Кузнецова I. К. асистент кафедри медичної біології Харківський національний медичний університет м. Харків, Україна

Хвороби органів травлення займають одне 3 провідних місць в структурі дитячої соматичної патології. Особливо турбує тенденція до зростання частки захворювань гепатобіліарної системи в структурі захворюваності та інвалідизації серед дитячого населення України. Серед чинників які можуть призводити до пошкодження печінки як матері так і плоду одне з головних місць належить раціону з надлишком поживних речовин [1]. Існує гіпотеза яка пов'язує розвиток пев- 